\title{
PERBEDAAN LAMA DAN JENIS PERSALINAN PADA IBU BEKERJA BERDASARKAN KEIKUTSERTAAN SENAM HAMIL
}

\author{
Hermin Yulianti ${ }^{1}$, Fariani Syahrul ${ }^{2}$ \\ r,2Departemen Epidemioloiri FKM \\ Universitas Airlangiga. Kampus C I Juiversitas Airlangea Nulyorejo 60115 \\ $\Lambda$ lamat Korespondensi; Hermin Yulianti \\ F-mail: hermin yuliantioutlook. oom
}

\begin{abstract}
Working during preghatev has negative effect for the health status of pregrant women. Exertises during pregnancy is one of the way to improve the health status of pregnant wrimen. The aim of researel wa to anatyze the differences of duration and type of childhirth hased on the exercises during pregnaney fin working mother: This research was un observational anulytic study with terospective cohort design. The exposed population was third trimester of pegnant women who worked and participated in presnancy exercises $>180$ minutes. The nonexposed population was third trimester of pregnant women who worked and paricipated in pregnancy exercises $\leq$ 180 minutes: Sample for the exposed group was 3 (l pregnant women and the non-exposed group was 60 pregnant women. The research analysis was to find the RR value with $95 \%$ Confidence Interval (CI). Pregnani women who participated in pregnency exercises hove a stort on nowal childbirth period 1.543 times than non-participated women Pregnant women who particinated in prognancl exercises have a normal type of childhirth 1256 timtes than ron-participated women. There were differences of duration and tipe of childbirth based on the pregnancy exercises on working mothen
\end{abstract}

Keywords: pregnancy exencise, working, childbinth duration, ehildbirth type

\section{ABSTRAK}

Bekerja selama kehamilan mempunyai efek negatit terhadap status kesehatan ihu hamil. Senam hamil merupakan salah satu upaya untuk meningkatkan status kesehatan pada ibu hamil. Penelitian ini bertujuan untuk menganalisis perbedaan lama dan jenis persalinan berdasarkan keikutsertaan senam hamil pada ibu yang bekerja di RSIA Siti Aisyah Surabaya. Penelitian ini menggunakan rancang bangun cohort retrospective dan merupakan studi analitik observasional. Populasi terpapar merupakan ibu hamil dan bekerja yang melakukan senam hamil $>180$ menil selama kehamilan trimester ketiga. Populasi tidak terpapar adalah ỉbu hamil yang bekerja dan melakukan senam hamil $\leq 180$ menit selama kehamilan trimester ketiga. Sampel untuk kelompok terpapar adalah 30 ibu hamil dan kelompok tialak terpapar berjumlah 60 ibu hamil. Analisis dalam pentitian ini bertujuan untuk menghitung nilai RR denian CI 95\%. Ibu hamil pada kelompok terpapar mengalami lama persalinan cepat atau normal 1,543 kali dibanding ibu pada kelompok tidak terpapar. Ibu hamil pada kelompok terpapar mengalami jenis persalinan normal 1.256 kali dibanding ibu pada kelompok tidak terpapar. Terdapat perbedaan lama dan jenis proses persalinan pada kelompok ibu hamil dan bekerja yang melakukan senam selama kehamilan dan tidak.

Kata kunci: senam hamil, bekerja, lama persalinan, jenis persalinan

\section{PENIAHULUAN}

Rata-rata angka partisipasi kerja perempuan secara global dari tahun $1990-2010$ mengalami peningkatan. Tingkat partisipasi kerja perempuan secara global sebesar $52 \%$ pada tahun 2010 (United Nation, 2010). Salah satu negara yang mengalami peningkatan angka partisipasi kerja perempuan adalah Indonesia yaitu sebesar $53,4 \%$ pada tahun 2014. Peningkatan partisipasi angkatan kerja pada tahun 2014 di Indonesia dipengaruhi oleh jumlah perempuan angkatan kerja yang meningkat di perkotaan. (International Labor Organization, 2015).

Tingkat angka partisipasi kerja perempuan di Jawa Timur tahun 2010 adalah sebesar 51,3\% pada tahun 2010. Angka partisipasi tersebut berada di atas rata-rata angka partisipasi kerja nasional yatu sebesar $46,8 \%$. Sehingga, tingkat partisipasi kerja perempuan di Provinsi Jawa 
Timur termasuk dalam kategori tinggi (BKKBN, 2013). Angka partisipasi kerja perempuan di Provinsi Jawa Timur mengalami penîngkatan menjadi $53,17 \%$ pada tahun 2014. Salah satu kota di Provinsi Jawa Timur dengan tingkat partisipasi kerja perempuan yang tinggi yaitu sebesar $53,26 \%$ pada tahun 2015 adalah Kota Surabaya (BPS, 2015).

Persentase usia kerja perempuan di Provinsi Jawa Timur di dominasi usia produkrif yaitu antara 15-49 tahun dan cenderung mengalami penuruman persentase pada usia 50-59 (BPS, 2015). Rata-rata usia menikalt pertama perempuan di daerah perkotaan seperti Surabaya adalah 20,53 tahun sedangkan di daerah pedesaan ratarata 18,94 tahun. Hal tersebut dipengaruhi tingkat partisipasi kerja wanita sebelum pernikahan sehingga dapat menunda usia pernikahan (Dinkes Jatim, 2012). Usia pernikahan berpengaruh terhadap usia kehamilan dan waktu melahirkan. Data tersebut menunjukkan bahwa rata-rata perempuan di Surabaya hamil dan melahirkan dalam usia angkatan kerja atau sedang bekerja. Bekerja selama hamil dapat memberikan efek negatif tethadap kesehatan selama hamil seperti perasaan khawatir atau tertekan, gangguan emosional dan kelelahan (Russel, et al, 2011).

Penelitian sebelumnya menyatakan bahwa ibu hamil sebaiknya mengurangi beban kerja selama kehamilan. Ibu hamil tanpa komplikasi kehamilan dapat tetap melakukan pekerjaan dengan aman. Ibu hamil yang bekerja di luar rumah disarankan untuk memperhatikan tingkat risiko pekerjaan yang dilakukan. Senam hamil yang dillakukan selama kehamílan pada ibu yang bekerja bermanfaat meminimalkan efek negatif selama bekerja (Rustam \& Sofian, 2012).

Salah satu layanan prenatal dan antenatal yang dapat diikuti ibu selama hamil adalah senam hamil. Beberapa tempat layanan kesehatan (klinik, puskesmas dan rumah sakit) menyelenggarakan program senam hamil sebagai salah satu bagian dari antenatal care. Keikutsertaan ibu dalam kelas senam hamil dipengaruhi oleh beberapa faktor antara lain usia, pendidikan, paritas, pendapatan keluarga dan dukungan sosial suami (Widiantari, 2015). Pendidikan dan pekerjaan berpengaruh terhadap keikutsertaan ibu dalam mengikuti senam hamil (Ayati, 2011; Ratnawati \& Utami, 2010).
Senam hamil yang dilakukan selama trimester ketiga diharapkan dapat membuat persalinan cepat, normal dan aman. Lama persalinan normal kala I fase aktif-kala II pada persalinan primipara adalah $5,7-14,6$ jam sedangkan pada persalinan multipara yaitu 2,79-6,5 jam (Friedman, 1978). Jenis persalinan normal merupakan persalinan yang terjadi tanpa induksi dan penggunaan alat untuk membantu proses persalinan (Mc. Lean, et al, 2013).

Senam hamil adalah satah satu faktor yang mempengaruhi kelancaran proses persalinan. Senam hamil bermanfaat untuk mempertahankan atau memperbaiki kondisi fisik saat dan pasea persalinan setelah tubuh mengalami stress karena janin yang berkembang. Ibu hamil yang melakukan senam hamil selama trimester ketiga memiliki lama persalinan lebih singkat dan tindakan dalam persalinan yang lebih sedikit. Senam hamil yang dilakụkan selamą kehamilan dapat mengurangi tingkat kecemasan ibu (Lewis \& Kennedy, 2011; Larasati \& Wibowo, 2012).

Senam hamil yang dilakukan secara teratur akan memperoleh beberapa keuntungan untuk meningkatkan kebugaran tubuh, terutama bagi ibu dengan persalinan primipara. Keuntungan tersebut antara lain relaksasi untuk mengatasi stres dan rasa sakit, membantu proses pembukaan serviks serta membuat aktivitas uterus merjadi terkoordinasi ketika bersalin. Lama persalinan yang lebih singkat dialami ibu yang melakukan seriam hamil selama trimester ketiga (Haswita, 2012).

Bukti ilmiah menunjukkan bahwa dengan berolahraga saat kehamilan dapat mengurangi waktu persalinan (length of labour) dan mengurangi komplikasi persalinan (Juhl, et al. 2010; Scott, 2006;). Senam hamil merupakan kegiatan (antenalal care) yang memberikan persalinan lebih baik karena dapat mampu mengendalikan faktor yang membuat persalinan lebih lama dengan cara meningkatkan tenaga atau kekuatan ibu saat mengalami persalinan. Secara keseluruhan senam hamil bermanfaat untuk peningkatan status kesehatan ibu hamil.

Penelitian lain juga menyatakan bahwa proses persalinan berhubungan bermakna dengan pelaksanaan senam hamil. Para ibu yang melakukan senam hamil selama kehamilan trimester ketiga terbukti dapat melalui proses 
persalinan dengant lancar dan lebih cepat dibanding dengan yang tidak melakukan senam hamil.

Senam hamil diperuntukkan bagi ibu hamil yang tidak mempunyai kelainan atau penyakit yang menyertai kehamilan seperti penyakit jantung, penyakit ginjal penyulit kehamilan (hamil dengan pendarahan) dan kehamilan yang disertai dengran anemia (Manuaba, 2010).

Definisi jenis persalinan normal yaitu persalinan tanpa ada induksi dan penggunaan ałat untuk membantu proses persalinan (Mc. Lean et al, 2013). Persalinan dengan tindakan merupakan persalinan yang membutuhkan alatalat kedokteran seperti vacuum ekstraksi, forceps ekstraksi dan ekstraksi bokong (posisi bayi sungsang) (Siswosuharjo dan Cakrawati, 2011). Lama persalinan normal kala 1 fase aktif-kala 2 pada persalinan primipara adalah 5,7-14,6 jam dan pada persalinan multipara antara 2,79-6,5 jam (Friedman, 1978).

Salah satu tempat pelayanan keseliatan di Kota Surabaya yang menyediakan kelas senam hamil adalah RSIA Siti Aisyah Surabaya. Tujuan penelitian ini adalah untuk mencari ada tidaknya perbedaan lama dan jenis proses persalinan berdasarkan keikutsertaan senam hanil selama kehamilan pada ibu yang bekerja di RSIA Siti Aisyah Surabaya. Tujuan khusus dari penelitian ini antara lain mengidentifikasi karakteristik ibu hamil (usia, tingkat pendidikan teraklir, pekerjaan dan paritas), mengidentifikasi pelaksanaar senam ibu hamil dan menganalisis perbedaan lama dan jenis proses persalinan berdasarkan keikutsertaan senam hamil pada ibu yang bekerja di RSTA Siti Aisyah Kota Surabaya.

\section{METODE}

Penelitian ini menggunakan rancang bangun penelitian kohort retrospektif dimana kelompok penelitian sudah mengalami efek, kemudian ditelusuri paparannya dan merupakan penelitian analytical observational study.

Populasi dalam penelitian int merupakan populasi terpapar dan tidak terpapar. Populasi terpapar adalah semua ibu hamil yang mengikuti senam hamil > 180 menit selama kehamilan trimester ketiga. Populasi tidak terpapar adalah semua ibu hamil yant mengikuti senam hamil $\leq 180$ menít selama kehamilan trimester ketiga. Kriteria inklusi dalam pengambilan data pada penelitian ini antara lain: Ibu hamil mempunyai pekerjaan selain ibu rumah tangga; Ibu hamil melakukan pemeriksaan kehamilan di RSIA Surabaya; dan Ibu hamil melakukan proses bersalin di RSLA Surabaya.

Penelitian ini menggunakan jumlah sampel dengan perbandingan kelompok terpapar dan kelompok tidak terpapar $=1 ; 2$. Sampel penelitian pada kelompok terpapar berjumlah 30 ibu hamil dan kelompok tidak teipapar berjumlah $60 \mathrm{ibu}$ hamil. Cara pengambilan sampel dengan acak bebas (simple random sampling) digunakan dalam penelitian ini.

Penelitian dilakukan setelah dilakukan kaji etik oleh tim kaji etik Fakultas Kesehatan Masyarakat Universitas Airlangga. Penelitian ini dilakukan di RSLA Siti Aisyah Surabaya dan mengzunakan data sekunder. Periode data yang diambil adalah 1 Maret 2016-31 Maret 2017.

Pengumpulan data dilakukan setelah memperoleh izin pengambilan data sekunder. Instrumen yang digunakan berupa form penelitian data sekunder berdasarkan riwayat pemeriksaan kehamilan dan keikutsertaan senam hamil. Data yang diambil yaitu data karakteristik ibu hamil (inisial, usia, pendidikan, paritas dan pekerjaan), riwayat keikutsertaan senam hamil, Iama persalinan dan jenis persalinan.

Data yang terkumpul diolah menggunakan aplikasi uji statistik. Setiap variabel dianalisis menggunakan teknik analisis univariat dimana setiap variabel dilihat distribusi dan tingkat persentasenya. Analisis untuk mengetahui ada tidaknya perbedaan lama dan jenis proses persalinan dilakukan dengan menghitung $95 \% \mathrm{CI}$ untuk melihat bermakna atau tidaknya nilai $R R$. Hasil perhitungan RR pada $95 \%$ CI dikatakan bermakna jika tidak melewati angka 1 .

\section{HASIL}

\section{Karakteristik Ibu Hamil}

Kelompok terpapar dalam penelitian merupakan ibu hamil yang bekerja dan melakukan senam hamil $>180$ menit selama trimester ketiga. Kelompok tidak terpapar adalah íbu hamil yang bekerja dan melakukan senam hamil $\leq 180$ menit selama trimester ketiga, 
Jumlah ibu hamil dalam penelitian adalah 30 orang untuk kelompok terpapar hamil dan 60 orang dalam kelompok tidak terpapar.

Kelompok terpapar menuikuti senam hamil selama $240-360$ menit dengan rata-rata \pm 276 menit selana trinester ketiga. Kelompok tidak terpapar mengikuti senam hamil selama 0 - 180 menit dengan rata-rata \pm 46 menit selama. trimester ketiga.

Karakteristik ibu hamil di RSLA Siti Aisyah Surabaya yang dilihat antara lain usia, tingkat pendidikan terakhir, paritas dan jenis pekerjaan. Usía íbu hamil pada penelitian ini berkisar antara 20-39 tahun dengan rata-rata usia 28 tahun dan paling banyak berusia 26 tahum.

Semua ibu hamil pada kelompok terpapar mempunyai interval usia 20-35 tahun. Kelompok tidak terpapar mayoritas mempunyai interval usia 20-35 tahuin yaitu sebanyak $90,0 \%$.

Ibu hamil di RSIA Siti Aisyah mempunyai jenjang pendidikan terakhir SMP, SMA dan Diploma/PT. Kelompok terpapar mayoritas memiliki jenjang pendidikan terakhir SMA yaitu sebanyak $53,3 \%$. Kelompok tidak terpapar mayoritas memiliki jenjang Pendidikan terakhir

Tabel 1. Distribusi lbu Hamil Menurut Usia di RSIA Siti Aisyah Surabaya Periode Maret 2016-Maret 2017

\begin{tabular}{lrrrr}
\hline \multirow{2}{*}{ Usia (tahun) } & \multicolumn{2}{c}{ Terpapar } & \multicolumn{2}{c}{ Tidak } \\
& \multicolumn{1}{c}{ Terpapar } \\
\cline { 2 - 5 } & n & $\%$ & \multicolumn{1}{c}{ n } & $\%$ \\
\hline $20-35$ & 30 & 100 & 54 & 90 \\
$>35$ & 0 & 0 & 6 & 10 \\
\hline
\end{tabular}

Tabel 2. Distribusi Ibu Hamíl Menurut Pendidikan di RSIA Siti Aisyah Surabaya Periode Maret 2016-Maret 2017

\begin{tabular}{lrrrr}
\hline \multirow{2}{*}{ Pendidikan } & \multicolumn{2}{c}{ Terpapar } & \multicolumn{2}{c}{$\begin{array}{c}\text { Tidak } \\
\text { Terpapar }\end{array}$} \\
\cline { 2 - 5 } & \multicolumn{1}{c}{$\mathbf{n}$} & \multicolumn{1}{c}{$\%$} & $\mathbf{n}$ & $\%$ \\
\hline SMP & 1 & 3,4 & 2 & 3,3 \\
SMA & 16 & 53,3 & 21 & 35 \\
Dipl/PT & 13 & 43,3 & 37 & 61,7 \\
\hline
\end{tabular}

Diploma/PT yaitu sebanyak $61,7 \%$. Berikut distribusi pendidikan ibu hamil pada kelompok terpapar dan tidak terpapar.

Ibu hamil yang bekerja dalam penelitian terdiri dari kelompok ibu dengan kehamilan primipara dan multipara. Kelompok terpapar dan tidak terpapar sebagian besar merupakan ibu hamil yang bekerja dengan persalinan multipara. Sebanyak $53,3 \%$ pada kelompok terpapar dan $61,7 \%$ pada kelompok tidak terpapar. Berikut distribusi paritas ibu hamil pada kelompok terpapar dan tidak terpapar.

Rata-rata ibu dengan kehamilan primipara mengikuti senam luamil selama \pm 160 menit: Rata-rata ibu dengan kehamilan multipara mengikuti senam selama \pm 93 menit selama trimester ketiga.

Semua ibu hamil dalam penelitian adalah ibu yang bekerja dengan pekerjaan sebagai PNS, swasta dan wiraswasta. Pelerjaan ibu hamil pada kelompok terpapar dan tidak terpapar mayoritas adalah swasta yaitu masing-masing sebanyak $76,7 \%$. Berikut distribusi pekerjaan ibu hamil pada kelompok terpapar dan tidak terpapar.

Tabel 3. Distribusi Ibu Hamil Menurut Paritas di RSLA Siti Aisyah Surabaya Periode Maret 2016-Maret 2017

\begin{tabular}{lcccc}
\hline \multirow{2}{*}{ Paritas } & \multicolumn{2}{c}{ Terpapar } & \multicolumn{2}{c}{ Tidak } \\
& \multicolumn{2}{c}{ Terpapar } \\
\cline { 2 - 5 } & n & $\%$ & n & $\%$ \\
\hline Primipara & 14 & 46,7 & 23 & 38,3 \\
Multipara & 16 & 53,3 & 37 & 61,7 \\
\hline
\end{tabular}

Tabel 4. Distribusí Ibu Hamîl Menurut Pekerjaan di RSIA Siti Aisyah Surabaya Periode Maret 2016 - Maret 2017

\begin{tabular}{lrrrr}
\hline \multirow{2}{*}{ Pekerjaan } & \multicolumn{2}{c}{ Terpapar } & \multicolumn{2}{c}{$\begin{array}{c}\text { Tidak } \\
\text { Terpapar }\end{array}$} \\
\cline { 2 - 5 } & \multicolumn{1}{c}{$\boldsymbol{n}$} & \multicolumn{1}{c}{$\%$} & \multicolumn{1}{c}{$\mathbf{N}$} & \multicolumn{1}{c}{$\mathbf{0}$} \\
\hline PNS & 3 & 10 & 3 & 5 \\
Swasta & 23 & 76,7 & 46 & 76,7 \\
Wiraswasta & 4 & 13,3 & 11 & 18,3 \\
\hline
\end{tabular}




\section{Gambaran Pelaksanaan Senam Hamil}

Salah satu fasilitas layanan kesehatan ibu hamil di RSIA Siti Aisyah adalah kelas senam hamil. Kegiatan tersebut dilakukan setiap hari Minggu dengan durasi \pm 60 menit. Jenis senam hamil yang dilakukan merupakan gabungan dari senam hamil pilates dan yoga.

Peserta senam hamil merupakan ibu hamil dengan kehamilain trimester ketiga yang didahului dengan pemeriksaan dan diperbolehkan mengikuti senam hamil oleh dokter. Kegiatan senam hamil dilakukan dengan terlebih dahulu memberikan infomasi waktu pelaksanaan oleh bidan pendamping.

Kelas senam hamil di RSIA Siti Aisyah Surabaya dilakukan di dalam ruang dengan sirkulasi udara dan pencahayaan yang cukup. Jenis senam hamil yang dilakukan merupakan gabungan dari gerakan senam hamil pilates dan yoga. Ruang yang disediakan untuk kelas senam hamil dilengkapi dengan matras dan bola pilates. Senam hamil dilakukan dengan panduan instruktur dan pendampingan oleh bidan yang mengetahui perkembangan kehamilan ibu sehingga dapat disesuaikan gerakannya.

\section{Perbedaan Lama Proses Persalinan}

Kelompok terpapar dan tidak terpapar dalam penelitian ini mengalami lamia proses persalinan cepat $_{\text {s normal dan lambat. Kelompok terpapar }}$ lebih banyak mengalami proses persalinan cepat: atau normal yaitu sebesar $90 \%$ dan persalinan lambat. Kelompok tidak terpapar sebagian besar mengalami proses persalinan lambat yaitu sebesar $41,7 \%$.

Tbu dengan kehamilan primipara dan multipara sebagian besar mempunyai lama persalinan cepat. Sebanyak $22,2 \%$ pada kelompok primipara dan $21,1 \%$ pada kelompok multipara.

Hasil perhitungan nilai RR dari Tama persalinan cepat dengan lama persálinan lambat menunjukkan tidak ada perbedaan pada kelompok terpapar dan tidak terpapar. Hasil perhitungan nilai $R R$ dari lama persalinan normal dengan lama persalinan lambat menunjukkan tidak ada perbedaan pada kelompok terpapar dan tidak terpapar. Lama persalinan cepat dan nomal merupakan kondisi non-patologis sehingga jumlati sampel kelompok persalinan normal
Tabel.5 Tabulasi Silang Lama Proses Persalinan Ibu Hamil Berdasarkan Keikutsertaan Senam Hamil di RSIA Siti Aisyah Surabaya Periode Maret 2016-Maret 2017

\begin{tabular}{lrrrr}
\hline \multirow{2}{*}{$\begin{array}{c}\text { Lama } \\
\text { Persalinan }\end{array}$} & \multicolumn{2}{c}{ Terpapar } & \multicolumn{2}{c}{$\begin{array}{c}\text { Tidak } \\
\text { Terpapar }\end{array}$} \\
\cline { 2 - 5 } & n & $\%$ & n & $\%$ \\
\hline Cepat Normal & 27 & 90 & 35 & 58,3 \\
Lambat & 3 & 10 & 25 & 41,7 \\
\hline
\end{tabular}

dan tepat digabungkan kemudian dihituing nilai RR.

Perhitungan RR dilakukan terhadap lama persalinan eepat atau normal dengan persalinan lambat dari kelompok terpapar dan tidak terpapar. Berikut distribusi lama persalinan ibu hamil berdasarkan keikutsertaan senam hamil.

Hasil perhitungan nilai $R R$ diperoleh bahwa kelompok terpapar yaitu ibu yang melakukan senam hamil $>180$ menit selama kehamilan trimester ketiga $1,543 \mathrm{kali}(95 \% \mathrm{Cl}$ $1,208<\mathrm{RR}<1,97 \mathrm{I})$ mengalamí lama persalinan cepat atau normal dibanding kelompok tidak terpapar yaitu ibu yant melakukan senam hamil. $\leq 180$ menit selama kehamilan trimester ketiga dan secara stastistik bermakna.

\section{Perbedaan Jenis Proses Persalinan}

Persalinan normal lebih banyak dialami ibu pada kelompok terpapar yaitu sebanyak $90 \%$. Persalinan disertai tindakan lebih banyak dialami pada kelompok tidak terpapar yaitu sebanyak $28,3 \%$.

Jenis persalinan normal lebih banyak dialami ibu dengan kehamilan multipara yaitu sebanyak $48,9 \%$ sedangkan pada kelompok

Tabel 6. Tabulasi Silang Jenis Proses Persalinan Tbu Hamil Berdasarkan Keikutsertaan Senam Hamil di RSIA Siti Aisyalr Surabaya Periode Maret 2016-Maret 2017

\begin{tabular}{lrccc}
\hline \multirow{2}{*}{$\begin{array}{c}\text { Jenis } \\
\text { Persalinan }\end{array}$} & \multicolumn{2}{c}{ Terpapar } & \multicolumn{2}{c}{$\begin{array}{c}\text { Tidak } \\
\text { Terpapar }\end{array}$} \\
\cline { 2 - 5 } & n & $\%$ & n & $\%$ \\
\hline Normal & 27 & 90 & 43 & 71,7 \\
Tindakan & 3 & 10 & 17 & 28,3 \\
\hline
\end{tabular}


primipara sebanyak $28,9 \%$. Jenis persalinan dengan tindakan lebih banyak dialami ibu pada kelompok primipara yaitu sebanyak 12,2\% sedangkan pada kelompok multipara sebanyak $10 \%$. Distribusi jenis persalinan ibu hamil berdasarkan keikutsertaan senam hamil terlihat pada Tabel 6.

Hasil perhitungan nilai RR diperoleh bahwa kelompok terpapar yaitu ibu yang melakukan senam hamil >180 menit selama kehamilan trimester ketiga 1,256 kali $(95 \%$ CI $1,029<R R<1,532)$ mengalami persalinan normal dibanding kelompok tidak terpapar yaitu ibu hamil dan bekerja yang melakukan senam. hamil $\leq 180$ menit dan mempunyai makna secara statistik.

\section{PEMBAHASAN}

\section{Karakteristik Ibu Hamil}

Ibu hamil dalam penelitian ini merupakan ibu hamil yang bekerja dan mengikuti kelas senam hamil di RSIA Síti Aisyal Surabaya pada periode 1 Maret 2016-31 Maret 2017. Karakteristik ibu hamil yang diteliti antara lain usia, tingkat pendidikan terakhir, pekerjaan dan riwayat kehamitan ibu. Kelonipok terpapar dalam penelitian ini merupakan ibu hamil yang bekerja. dan melakukan $>180$ menit senam selama kehamilan trimester ketiga, Kelompok tidak terpapar dalam penelitian ini merupakan ibu hamil yang bekerja dan melakukan $\leq 180$ menit senam selama kehamilan trimester ketiga.

Usia ibu hamil pada kelompok terpapar dan tidak terpapar sebagian besar terletak pada. interval usia 20-35 tahun dengan persentase sebesar $100 \%$ pada kelompok terpapar dan sebesar $90 \%$ pada kelompok tidak terpapar. Interval usia 20-35 tahun adalah usia produktif perempuan untuk bekerja (BPS, 2015).

Pendidikan terakhir ibu hamil pada kelompok terpapar mayoritas adalah SMA yaitu sebesar $53,3 \%$. Pada kelompok tidak terpapar sebagian besar mempunvai tingkat pendidikan terakhir PT Diploma. Ibu yang memiliki tingkat pendidikan terakhir lebih tinggi akan mengalokasikan lébih banyak waktu untuk bekerja sehingga memiliki jumlah jam lebih sedikit untuk mengikuti kelas senam lamil (Marita \& Waridin, 2013).
Kelompok terpapar dan tidak terpapar sebagian besar merupakan ibu dengan kehamilan multipara. Hasil penelitian tersebut berbeda dengan penelitian sebelumnya yang menyatakan bahwa ibu dengan kehamilan primipara lebih banyak mengikuti senam hamil (Widiantari, 2015). Keikutsertaan ibu dalam kelas senam hamil bisa dipengaruhi oleh pengalaman kehamilan dan melahirkan sebelumnya serta ada tidaknya anak yang masih memerlukan pengasuhan ibu di rumah (Gaston \& Cramp, 2011). Pengalaman kehamilan dan melahirkan sebelumnya mempengaruhí pola pikir ibu untuk meningkatkan derajat kesehatannya selama hamil dan melahirkan dengan mengikuti kelas senam hamil. Salah satu faktor yang mempengaruhi seseorang dalam mengambil keputusan atau tindakan adalah pengalaman masa Jalu (Dietrich, 2010). Pengalaman masa lalu yang negatif cenderung membuat seseorang tidak akan mengulangi tindakan yang pernah dipilih. Seseorang akan mengulang tindakan yang sama di masa lalu jika tindakan tersebut mempunyai pengaruh positif. Seseorang cenderung membuat pilihan yany lebih baik pada kesempatan berikutnya (Sagi \& Friedland, 2007).

Pekerjaan ibu hamil pada kelompok terpapar maupun tidak terpapar mayoritas adalah swasta. Pekerjaan swasta mempunyai jam kerja yang bervariasi antara perusahaan satu dengan lainnya. Perusahaan swasta memberlakukan 5 hari kerja (Senin-Jum'at) dan 6 hari kerja (Senin-Sabtii) dalan seminggu, Ibu hamil yang bekerja di perusahaan swasta dengan 5 hari jam kerja bisa menggunakan hari Sabtu untuk berkumpul dengan keluarga dan masih dapat mengikuti kelas senam hamil pada hari Minggu. Ibu hamil yang bekerja dengan 6 hari kerja menggunakan hari Minggu untuk berkumpul dengan anggota keluarga sehingga tídak dapat mengikuti kelas senam hamil. Hal tersebut sejalan dengan penelitian sebelumnya bahwa partisipasi jbu hamil dalam mengikuti kelas senam hamil dipengaruhi oleh tingkat kesibukan ibu dalam bekerja (Ratnawati dan Utami, 2010).

\section{Perbedaan Lama Persalinan}

Frekuensi senam hamil yang diikuti ibu selama kelamilan trimester ketiga kelompok 
terpapar $>180$ menit yaitu berkisar antara 240-360 menit: Kelompok tidak terpapar mengikuti senam hamil $\leq 180$ yaitu berkisar antara $0-180$ menit

Selama kehamilan trimester ketiga. Hasil penelitian menunjukkan terdapat perbedaan lama proses persalinan pada kelompok terpapar dan tidak terpapar. Tbu hamil dan bekerja yang melakukan senam hamil dengan durasi $>$ 180 menit selama kehamilan trimester ketiga mempunyai pertgaruh positif terhadap lama persalinan.

Kelompok ibu hamil dan bekerja yang melakukan senam hamil $>180$ menit selama kehamilan trimester ketiga sebagian besar (60\%) mengalami persalinan cepat. Kelompok ibu hamil dan bekerja yang melakukan senam hamil $\leq 180$ menit selama kehamilan trimester ketiga sebagian besar $(41,7 \%)$ mengalami persalinan lambat,

Hasil perhitungan nilai Risiko Relatif diperoleh nilai $1,543 \quad(95 \%$ CI $1,208<\mathrm{RR}<1,971)$. Hasil tersebut menuinjukkan bahwa ibu hamil yang bekerja dan melakukan senam hamil $>180$ menit selama trimester ketiga 1,543 kali mengalami persalinan cepat atau nomal dibanding dengan ibu yang melakukan senam hamil $\leq 180$ menit selama trimester ketiga dan bermakna secara statistik.

Hasil penelitian tersebut sejalan dengan penelitian sebelumnya oleh Mariani dan Puspitasari (2006) menyatakan bahwa ibu yang melakukan senam hamil terbukti dapat melalui persalinan lebih cepat dibanding dengan yang tidak mengikuti senanı hamil. Bukti ilmiah menunjukkan dengan senam hamil selama kehamilan dapat mengurangi waktu persalinan dan komplikasi selama persalinan (Juhl, et al., 2011). Penelitian yang dilakukan oleh Shefield (2012) menyatakan terdapat efek positif senam hamil terhadap lama persalinan yang dilakukan selama kehamilan.

Hasil penelitian tersebut juga sesuai dengan teori manfaat senam hamil yaitu memperoleh kekuatan yang baik pada otot perut, otot dasar panggul, dan membuat badan ibu hamil lebih bugar. Hal tersebut merupakan faktor yang berhubungan dengan kelancaran proses persalinan. Senam hamil yang dilakukan selama kehamilan trimester ketiga secara teratur akan menuntun ibu hamil ke arah persalinan fisiologis.
Senam hamil yang dilakukan selama kehamilan dapat memanipulasi atau mengendilikan faktor yang menyebabkan persalinan ibu menjadi lama dengan cara meningkatkan kekuatan ibu ketika bersalin.

\section{Perbedaan Jenis Persalinan}

Kelompok ibu hamil dan bekerja yang melakukan senam hamil $>180$ menit selama kehamílan trimester ketiga sebagian besar $(90 \%)$ mengalami persalinan normal (tanpa tindakan). Kelompok ibu hamil dan bekerja yang mengikuti senam hamil $\leq 180$ menit terdapat $28,3 \%$ ibu hamil yang melakukan persalinan dengan disertai tindakan.

Hasil perhitungan nilai RR diperolèh nilai $1,256(95 \%$ CI $1,029<\mathrm{RR}<1,532)$. Hasil tersebut memperlihatkan bahwa ibu hamil dan bekerja yang mengikuti senam hamil $>180 \mathrm{menit}$ selama trimester ketiga 1,256 kali melakukan persalinan normal dibanding dengan ibu hanil yang bekerja dan melakukan senam hamil $\leq 180$ menit selama kehamilan trimester ketiga dan bermakna secara statistik.

Ibu hamil yang mengikuti senam hamil sebanyak minimal 180 menit selama kehamilan mengalami persalinan normal $1,379 \mathrm{kali}$ dibandingkan ibu hamil dengan frekuensi senam hamil kurang dari enam kali selama kehamilan. Lebih dari $50 \%$ ibu pada penelitian tersebut merupakan ibu hamil yang bekerja (Widyawati \& Syahrul, 2013).

Hásil penelitian yăng sama juga dipaparkan oleh Hall (1987) yang menyatakan bahwa ibu hamil yang tidak melakukan latihan fisik selama kehamilan berisiko untuk empat kali mengalami persalinan caesar yang termasuk dalam persalinan dengan tindakan dibanding ibu yang melakukan latihar fisik atau senam selama kehamilan.

Ibu yang tidak mengikuti senam hamil mayoritas mengalami persalinan dengan tindakan berupa caesar, pemberian Oksitosin, dan ekstraksi vakum. Sebagian besar ibu hamil dan bekerja masih mengalami persalinan dengan tindakan sehingga ibu hamil yang bekerja dianjurkan untuk tetap melakukan senam hamil.

Hal tersebut sesuai dengan penelitian sebelumnya bahwa bekerja selama hamil dapat memberikan efek negatif seperti perasaan 
tertekan dan kelelahan (Russel, et al., 2011). Salah satu cara untuk mengurangi efek negatif tersebut adalah dengan melakukan senam hamil (Rustam \& Sofian, 2012).

Senam hamil yang dilakukan secara teratur selamia kehamilan dapat menurunkan risiko terjadinyą persalinan caesar (Owe, et al., 2016; Hinman, et al., 2015).

\section{SIMPULAN DAN SARAN}

\section{Simpulan}

Terdapat perbedaan lama dai jenis proses persalinan pada ibu hamil dan bekerja yang mengikuti senam hamil $\geqslant 180$ menit selama kehamilan trimester ketiga dengan yang melakukan senam hamil selama $\leq 180$ menit selama kehamilan trimester ketiga. Kelompok ibu hamil dan bekerja yang melakukan senam hamil $>180$ menit 1,543 kali mengalani lama persalinan cepat atau normal dibandingkan kelompok ibu hamil dan bekerja yang melakukan senam hamil $\leq 180$ menit. Kelompok ibu hamil dan bekerja yang melakukan senam hami $>180$ menit 1,256 kali mengalami persalinan normal dibandingkan kelompok ibu hamil dan bekerja yang melakukan senam hamil $\leq 180$ menit.

\section{Saran}

Ibu hamil dan bekerja agar tetap mengikuti kelas senam hamil $>180$ menit selama kehamilan trimester ketiga untuk menghadapi proses persalinan. Tempat layanan kesehatan yang mempunyai program kelas senam hamil meningkatkan promosi mengenăi program tersebut. Terdapat keterbatasan dalam penelitian yaitu penelitian hanya melihat lama dan jenis proses persalinan pada ibu yang bekerja berdasarkan "Klasifikasi Baku Jabatan Indonesia" menurut BPS tahun 2014, sehingga untuk menunjang hașil penelitian ini perlu dilakukan perhitungan beban kerja ibu selama bekerja dan disertai keikutsertaan senam hamil serta diperlukan penilaian tingkat aktivitas ibu di luar waktu untuk bekerja.

\section{DAFTAR PUSTAKA}

Ayati, N. 20l1. Karakteristik Ibu Hamil yang Memengaruhi Keikutsertaan Senam Hamil di BPS "M" Wates Magersari Mojokerto. Hrispital Majapahit, 2(3). http://poltekkesmajapahit. ac. id/downlot.php? file $=$ Hospital $\% 20$ Majapahit $\% 20 \mathrm{Vol} \% 203 \% 20 \mathrm{No} \% 202$,pdf.

BKKBN. 2013. Profil Kependudukan dan Pembangunan Indonesia Tahun 2013, s.1.: BKKBN, http:/chnrl.org/pelatihan-demografi/ Profil-Kependudukan-dan-Pembangunan-diIndonesia-Tahun-2013.pdf,

BPS. 2015. Indikator Pasar Tenaga Kerja Indonesia Februari 2015, Jakarta: BPS. https:// media.neliti.com/media/publications/48785ID-indikator-pasar-tenaga-kerja-indonesiafebruari-2015.pdf.

Dietrich, C. 2010. Decision Making: Factors that Influence Decision Making, Heuristics Used, and Decision Outcomes. Inquiries Jounnal Siudent Pulse, 2(2).

Dinkes Jatim. 2012. Profil Keschatan Profinsi Jawa Timur 2012. Surabaya: Dinas Kesehatan Provinsi Jawa Timur:

Friedman, E.A. 1978. Labor: Clinical Evaluation and Management Ed2. Norwalk: AppletonCentury-Croff.

Gaston, Anca., Cramp, Anita. 2011. Exercise During Pregnancy: A Review of Patterns and Determinants. Journal of Science and Medicine in Sporl, 14(4). pp. 299-305.

Hall, D.C; Kaufmann, D.A. 1987. Effect of Aerobic and Strenght Conditioning on Pregnancy Outcomes. Am J Gynecal. 157, pp. 1199-1203.

Haswita, S. 2012. Hubungan Motivasi Tbu Hamil dengan Pelaksanaan Senam Hamil di Dusun Krajan Desa Jambewangi Wilayah Kerja Puskesmas Sempu Banyuwangi Tahun 2012. E-Journal Akes Rustida. http:/e-journal.akesrustida.ac.id/folder files/2015051101304 Ipecah01.pdf.

Hinman, Sally K., Smith, Kristy B., Quillen, David M., Smith, M Seth. 2015. Exercise in 
Pregnancy: A clinical Review. SAGE Joumal, 7.6).

International Labor Organization. 2015. Tien Ketenagakerjaan dan Sosial di Indonesia 2014-2015. Jakarta: ILO.

Juhl, M., Olsen, J., Andersen, A.N. 2010. Physical Exercise During Pregnancy and Fetal Growth Measures: A Study Within Danish National Birth Cohort. Am Johstet Gynecol, 202(63), spp. $1-8$.

Larasati, Inka Puty., Wibowo, Arief. 2012. Pengarth Keikutsertaan Senam Hamil terhadap Kecemasan Primigravida Trimester Ketiga dalam Menghadapi Persalinan. Jumal Biometrika dan Kependudukan, I(I), pp. 2632.

Lewis, Beth, A., Kennedy, Betsy F, 2011, Effects of Exercise on Depression During Pregnancy and Postpartum; A Review. American Journal of Lifestyle Medicine, 5 (t).

Manuaba. 2010. Itmu Kebidanan, Penyakit Kandungan dan KB. 2 penyunt. Jakarta: EGC Penerbit Buku Kedokteran.

Mariani \& Puspitasari, N. 2006. Praktik Senam Hamîl, Hubungannya dengan Kelancaran Proses Persalinan. The Indonesian Journal of Public Health, 3(1), pp. 10-14. http:t download.portalgaruda.org/article.php?art icle $=17946 \& \mathrm{val}=1114 \&$ title $=$ Praktik $\% 20$ Senam $\% 20 \mathrm{Hamil} \% 20 \mathrm{Hubungannya} \% 20$ dengan $\% 20 \mathrm{Kelancaran} \% 20$ Proses $\% 20$ Persalinan.

Marita \& Waridin, 2013. Analisis Pengaruh Upah, Pendidikan, Jumlah Tanggungan Keluarga dan Status Perkawinan terhadap Curahan Jam Kerja Wanita di Kecamatan Pedurungan dan Kecamatan Tembalang, Kota Semarang. Diponegoro Journal of Economics, I(2).

Mc. Lean, M. Chenery, S. \& Morris. 2013. Normal Midwifery Practice SAGE Publication.

Owe, Mari Katherine, Nystad, Wence, Stigum, Hein., Vangen, Siri, Bopt, Kari. 2016. Exercise During Pregnancy and Risk of Cesarean Delivery in Nullparous Women: A Large Population-Based Cohort Study. American
Journal of Obstetrics and Gynecology, $2(34)$.

Ratnawati, S. \& Utami, S. 2010. Hubungan antara Pekerjaan dengan Partisipasi Ibu Mengikuti Senam Hamil di URJ Poli Hamil II RSUD Dr, Soetomo Surabaya. Jurnal Penelitian Kesehatan Suara Forkes, 1(3). http:/static. schoolrack.com/files/100398/295416/ volumel nomor 3 .pdf.

Russel, H., Watson, D. \& Banks, J, 2011. Pregnancy at Wark: A National Survey, Dublin: HSE Crisis Pregiancy Prograin.

Rustam, M. \& Sofian, A. 2012. Sinopsis Obstetri: Obsteni Fisiologi, Obstetri Patologi Jilid 1 2 penyunt. Jakarta: EGC Emergency Arcan Buku Kedokteran.

Sagi, A, \& Friedland, N, 2007. The Cost of Richness: the Effect of the Size and Diversity of Decision Sets on Post-Decision Regret. Hournal of Personality and Sociat Psychology, 93(4), pp. 515-524.

Scott, S. 2006. Exercise During Pregnancy. ACSM'S Health \& Filness Journal, 10 2).

Shefield, Barbara. 2012. Physical Activity and Pregnancy. Springer Link: Sport Medicine, $23(1)$, pp. $33-47$.

Siswosuharjo, Suwignyo., Cakrawati, Fitria. 2011. Panduan Kehamilan Super Lengkap. Jakarta: Penebar Plus.

United Nation. 2010. The Worlds Women 2010: Trends and Statisties, New York. http:// unstats.un org/unsd/demographic/products/ Worldswomen WW_full\%20report_color. pde.

Widiantari, N.K.N. 2015. Hubungan Karakteristik Ibu dan Dukungan Sosial Suami dengan Partisipasi Tbu Mengikuti Kelas Ibu Hamil di Kota Denpasar Disertasi.

Widyawati \& Syahrul, F, 2013. Pengaruh Senam Hamil terhadap Proses Persalinan dan Status Kesehatan Neonatus, Jurnal Berkala Epidemiologi, Vol 1, pp. 316-324. http $/$ t journal unairac.id/download-fullpapersjbe53f8249247full.pdf. 